\title{
Biyomimetik Tabanlı Fonksiyonel Yürüteç Tasarımı ve Dijital İnsan Modelleme ile Ergonomik Analizi
}

\author{
Neslihan TOP $^{1 a^{*}}$, Hüdayim BAŞAK ${ }^{1 b}$, İsmail ŞAHİN ${ }^{1 c}$ \\ ${ }^{1}$ Gazi Üniversitesi, Teknoloji Fakültesi, Endüstriyel Tasarım Mühendisliği Bölümü, 06560 Ankara, Türkiye \\ neslihantop@gazi.edu.tr
}

\begin{abstract}
Received/Geliș: 05.01.2021
Accepted/Kabul: 01.03.2021

Öz: Hastalık veya kaza gibi sebeplerle bireylerin bacak, diz, kalça vb. bölgelerinde ortopedik rahatsızlıklar meydana gelebilmektedir. Bu rahatsızlıkların tedavisinde, hastanın mümkün olan en kısa sürede iyileşebilmesi için fiziksel aktivitelere başlanması gereklidir. Baston, koltuk altı değneği, kanedyen ve yürüteç gibi ürünlerden destek alınarak hastanın daha kolay yürümesi sağlanmaktadır. Ayrıca, ileri yaştaki bireylerde kas ve iskelet sisteminin gücünü kaybetmesi sebebiyle meydana gelen denge sorununa engel olmak amaciyla yürüteçlerden faydalanılmaktadır. Bu çalışmada, biyomimetik yaklaşım kullanılarak modüler özellikte, fonksiyonel bir yürüteç tasarlanmıştır. Tasarımın modüler özelliği sayesinde ihtiyaç durumuna göre oturma birimi olma ve katlanabilme fonksiyonları bulunmaktadır. Yürüteç tasarımının ergonomik risk değerlendirmesi CATIA V5 yazılımındaki Hızlı Tüm Vücut Değerlendirmesi (Rapid Entire Body Assesment - REBA) ve Hızlı Üst Ekstremite Değerlendirmesi (Rapid Upper Limb Assessment - RULA) araçları ile Dijital İnsan Modelleme (Digital Human Modeling - DHM) kullanılarak gerçekleştirilmiştir. Analiz sonuçlarına göre yürüteç tasarımında değişiklik gerektirecek seviyede bir ergonomik risk değeri tespit edilmemiştir.
\end{abstract}

Anahtar Kelimeler: Biyomimetik, ergonomi, DHM, yürüteç tasarımı

\section{Biomimetic Based Functional Walker Design and Ergonomic Analysis with Digital Human Modeling}

\begin{abstract}
Orthopedic disorders may occur in the leg, knee, hip etc. regions of the individuals due to illness or accident. In the treatment of these ailments, it is necessary to start physical activities in order for the patient to recover as soon as possible. The patient can walk more easily by getting support from products such as canes, armpit sticks, cane and walkers. In addition, walkers are used to prevent balance problems in elderly people due to the loss of strength of the musculoskeletal system. In this study, a functional and modular walker was designed using a biomimetic approach. Thanks to the modular feature of the design, it has the functions of being a seating unit and folding according to the need. Ergonomic risk assessment of the walker design was performed using the Rapid Entire Body Assessment (REBA) and Rapid Upper Limb Assessment (RULA) tools in CATIA V5 software using Digital Human Modeling (DHM). According to the analysis results, an ergonomic risk value that would require a change in the walker design was not determined.
\end{abstract}

Keywords: Biomimetics, ergonomics, DHM, walker design

\section{Giriş}

Alt ekstremite problemi olan dezavantajlı bireyler, ortopedi hastaları ve yürüme zorluğu çeken ileri yaştaki bireylerde dengeyi sağlayabilmek veya protez üzerine yüklenmemek amacıyla yürüteç kullanılmaktadır. Yürüteçler, baston kullanımına göre bireye daha fazla destek sağlamaktadır. Kullanım durumuna göre değişkenlik gösteren; katlanan, tekerlekli, oturma kısmına sahip, sepetli gibi çeşitli modeller bulunmaktadır. Farklı boy ölçüsündeki bireylere göre yüksekliği ayarlanabilen, 
vücut duruşunu düzenleyen tasarımların kullanımı daha ergonomiktir. Yürüteç kullanımı ile bireylerin evden bağımsız olması sağlanarak hayat standartları yükseltilmektedir. Yürütecin kullanımı sırasında, bireyin kolları tutamaklara sarılı ve kolların dirsekten bükülü olması doğru duruş pozisyonunu temsil etmektedir [1-3].

Yürüteçler, hastalık, kaza vb. sebeplerle ameliyat sonrasında diz, bacak ve kalça bölgelerine yürüme esnasında destek olunması amaciyla kullanılmaktadır. Ayrıca, ameliyat sonrası protez kullanmak zorunda olan bireylerde doktor tavsiyesi ile birlikte yürüteç desteği sağlanmaktadır. İleri yaştaki bireylerde hastalık durumu olmasa bile dengeyi sağlamak ve yürümeyi kolaylaştırmak amacıyla yürüteç kullanımı tercih edilmektedir. Kanedyen, baston ve koltuk altı değneğine göre tekerlekli yürüteçler bireye daha fazla destek olmaktadır. Kişiye yürüme desteği sağlayan bu ürünlerden hangisinin kullanılacağı bireyin hastalık durumu, yaşı, kilosu ve hekim kararına göre belirlenmektedir [4, 5]. Yürütecin kullanım sürecinde, bireyin sağlam ayağı ile bir adım atması sırasında yürüteç tutamaklarından ittirilerek güçsüz ya da problemli olan ayak sağlam ayağın yanına getirilmektedir [6].

Anatomik ve fizyolojik bozukluklar, bireysel potansiyeli kısıtlamakta ve çevresel etkinliği azaltmaktadır. Yürüteç kullanımı, bireyin fonksiyonel bağımsızlığını arttırarak daha özgür hissetmesine izin vermekte ve yaşam kalitesini arttırmaktadır. İleri yaştaki bireylerin mesleki faaliyetleri minimum düzeyde olduğu için psikolojik gelişim ve fiziksel aktivitelerin devamlılı̆̆ için fonksiyonel hareketlilik oldukça önemlidir. Hareket yeteneğinin kısıtlanması, ilerleyen zamanlarda kas ve iskelet sisteminde işlev kayıplarına sebep olabilmektedir. Yapılan egzersizler ile kaybolan işlevler ve bozulan vücut duruşu düzeltilmektedir [7-9].

İleri yaştaki bireylerde yaşanan denge problemi sebebiyle düşme sonucu kırıklar meydana gelebilmektedir. Kalça kırıkları bu süreçte sıklıkla karşılaşılan problemlerden biridir. İyileşme sürecinde, kırık öncesi faaliyetlerin tekrarlanabilmesi için gerekli fiziksel aktivitelerin yapılması ve hastanın yatağa bağımlılığının azaltılması gereklidir. Ameliyat sonrası hastaları bir an önce ayağa kaldırabilmek amacıyla fonksiyonel yürüteç tasarımları kullanılmaktadır [10].

Fizyoterapistler, hasta ve yaşliların mevcut sorunlarına uygun olarak klasik baston, koltuk altı değneği, kanedyen veya yürüteç kullanımını önermektedir. Klasik baston kullanımı sırasında bireylerin vücut ağırlığının \%15-\%20'sinden fazlasını aktardığı görülmüştür $[11,12]$. Yürüteçlerin sabit, tekerlekli ve motorlu olmak üzere farklı fonksiyona sahip çeşitleri bulunmaktadır. Yürümeye yardımcı olarak kullanılan ürünler arasında kişiye en çok desteği sağlayan fakat en çok dikkati gerektiren yürüteçlerdir [13]. Yürüteç kullanımında bireyin duruş pozisyonu, el ve bilek fleksiyon ve ekstansiyon açıları önemlidir. Ergonomik bir duruş pozisyonu ile uzun süreli yürüyüşlerde bireyin kas ve iskelet sistemine rahatsızlığa sebep olmayacak tasarımlar geliştirilmelidir. Yürüteç ile birlikte taşınması gereken eşyalar için ayrı bir taşıma bölümü sağlanarak aracın dengesini bozmadan yürüyüşün devamlılığı sağlanmalıdır. Gerekli olan durumlarda kişilerin dinlenmesine izin verecek oturma alanı bulunmalıdır. Yürüteçler ile birlikte toplu taşıma araçlarına binmek durumunda kalınması göz önünde bulundurularak ihtiyaç halinde kolay bir şekilde katlanabilen yürüteç tasarımı gereklidir.

Sabit ayaklı standart yürüteç, sadece ön ayakları tekerlekli ve dört tekerlekli yürüteç tasarımları mevcuttur [12]. Sabit ayaklı yürüteçler, denge problemi olan ileri yaştaki bireyler için uygundur ancak yüksek dikkat gerektirmektedir [14]. Hasta ve yaşlı bireyler bu yürüteci kaldırmakta sıkıntı çekebilirler. Ön tekerlekli yürüteçler, sabit ayaklı yürüteçlere göre daha periyodik ve sürekli bir yürüyüşe izin vermektedir. Dört tekerlekli yürüteçler ise diğer tasarımlara göre kişiye daha çok destek sağlayarak uzun süreli yürüyüşlere izin vermektedir. $\mathrm{Bu}$ tasarıma eklenebilen farklı fonksiyonlar ile daha konforlu ve sağlıklı yürüyüşlerin yapılması mümkündür. 
Bu çalışmada, modüler özellikte ve çok fonksiyonlu yürüteç tasarımı armadillo ve tespih böceği organizmalarından esinlenilerek geliştirilmiştir. Tasarım, ihtiyaç doğrultusunda farklı açılarda katlanabilir ve oturma birimi haline gelebilir özelliktedir. Modüler sistem ile elde edilen, farklı büyüklükteki taşıma hazneleri tasarıma eklenmiştir. Tasarımın ana hatları alüminyum konstrüksiyon ile oluşturulmuş ve ara bağlantılar su geçirmez kumaş ile kaplanmıştır. Bu durum, ürün ağırlığının azaltılmasını sağlamış ve bireylerin yürüyüşünü kolaylaştırmıştır. Bilgisayar Destekli Tasarım (CAD) ortamında üç boyutlu (3B) modeli oluşturulan yürüteç tasarımının ergonomik risk analizi CATIA V5 programının Hızlı Tüm Vücut Değerlendirmesi (Rapid Entire Body Assesment REBA) ve Hızlı Üst Ekstremite Değerlendirmesi (Rapid Upper Limb Assessment - RULA) araçları kullanılarak Dijital İnsan Modelleme (Digital Human Modeling - DHM) ile gerçekleştirilmiştir.

\section{Biyomimetik Yaklaşımı}

Biyomimetik terimi, yunanca hayat (bios) ve taklit (mimesis) anlamına gelen kelimelerin birleşimi ile elde edilmiştir ve doğadan ilham alma anlamında kullanılmaktadır [15]. Doğada var olan biyolojik yapılardan esinlenilerek ya da benzetme yapılarak yeni tasarımlar geliştirilmektedir [16]. Doğada var olan pek çok organizma başarılı tasarımların üretimine olanak sağlamıştır. Doğadaki çözümler, mühendis ve tasarımcılar tarafından taklit edilerek sistemdeki mevcut problemlerin çözümünde kullanılmaktadır [17].

Biyomimetik, yeni bir metodoloji olarak kabul edilmesine rağmen yüzyıllardır pek çok yeni ürün geliştirme sürecinde doğada var olan organizmalar biçim, işleyiş, renk, hayatta kalma prensibi ve hareket etme şekli bakımından taklit edilmiştir [18-20]. İnsanlar eski çağlarda yaşadıkları mağaraların yapısını taklit ederek korunma amaçlı sığınakları inşa etmişlerdir [21, 22]. Doğadaki organizmaların doğal yeteneğinin tasarım ve mühendislik süreçleriyle ilişkilendirilmesi ile yeni malzeme, sistem, mekanizma ve araçlar geliştirilmiştir. Akıllı malzemeler, yapay zekâ, bal peteği yapıları ve pompa mekanizması gibi pek çok sistem ve ürün doğadan ilham alınan teknolojilere örnek olarak gösterilebilir [23].

Biyomimetik, biyomimikri ve biyonik gibi kelimelerle benzer anlamda kullanılmakla birlikte kullanım alanı bakımından farklılık göstermektedir. Biyonik terimi daha çok tıp alanındaki benzetmelerde kullanılırken, biyomimetik ve biyomimikri endüstriyel tasarım ve mühendislik presiplerinde doğadan ilham alma ifadesini karşılamaktadır [15, 24]. Biyomimetik terimi ile birlikte kullanılan kavramlardan biri olan biyomekanik, mühendislik ve biyoloji bilimleri ortak bir disiplinde birleştirilmiştir. Biyolojik olarak canlıların hareketinin nasıl sağlandığı ve kontrol edildiği, hareket sırasında meydana gelen kuvvet ve zorlanmalar detaylı bir şekilde incelenerek mühendislik yöntemleriyle birleştirilmektedir [25].

Mikro ve makro düzeyde pek çok teknolojinin gelişiminde mühendis ve tasarımcılar, benzersiz ve yenilikçi bir ürün geliştirebilmek için doğadaki çözümlere başvurmaktadır. Endüstriyel tasarım alanındaki patent ve faydalı modeller arasında birçok biyomimetik tabanlı tasarım bulunmaktadır. $\mathrm{Bu}$ tasarımlardan biri, ana çevresi balık şeklinde olan biyomimetik tabanlı su altı kamerasıdır. Kamera, T şeklinde destek, kontrol devre kartı, sallanan dişli ve batır-yüzdür mekanizması içermektedir. Kameranın mekanizması, dıș iskeletin duvarlarına tutunan T șeklindeki destek yapı üzerine sabitlenmiştir. Optimize edilmiş, balık şeklindeki dış iskeletin uç kısmına kamera yerleştirilerek basit ve kolay sökülebilen bir sistem oluşturulmuş ve kameranın su altındaki kullanımı kolaylaştırılmıştır [26]. Başka bir biyomimetik tabanlı mühendislik tasarımında ise destek elemanının bir pivot cihaz etrafında verimli hareket edebilmesi için biyomimetik tabanlı mekanik mafsal konfigüre etme yöntemi kullanılmıştır. Mekanik eklemlerin doğasında bulunan verimsizlik, biyomimetik eklemler ile giderilmiştir. Biyomimetik tabanlı endüstriyel robotların daha hassas ve güçlü olabildiği bildirilmiştir [27]. Bir diğer patentli tasarımda, çok sayıda elektrot arasındaki direnç ölçülerek çalışan sensörler setinden oluşan biyomimetik bir duyusal sistem geliştirilmiştir. 
Elektrotlar, deforme olabilen yapıların üzerini örterek dış nesnelerle doğrudan temastan korunan, sert bir yapı üzerine yerleştirilmiştir. Bu mekanik yapılar, el distal falanksı, üzerini örten parmak pulpası ve tırnağı örten biyolojik ilişkilerle benzerlik göstermektedir. Algılanacak uyaranları tanımlamak için bu sensörlerden sinyal bilgisi çıkarılmaktadır [28].

\section{Biyomimetik Tabanlı Yeni Bir Yürüteç Tasarımı}

Çalışmada, katlanabilir özellikteki tekerlekli yürüteç tasarımı biyomimetik yaklaşımdan faydalanılarak tasarlanmıştır. Tasarım sürecinde ön planda tutulan "katlanabilirlik, fonksiyonellik ve modülerlik" kavramları doğada var olan organizmaların ve biyomimetik tabanlı çalışmaların bulunduğu AskNature sitesinde taranmıştır [29]. İlk olarak katlanabilir (foldable) ifadesi aratıldığında değerlendirilebilir sonuçlar elde edilememiştir. Daha sonra yuvarlanabilir (rolling) ifadesi "modify size/shape/mass/volume" fonksiyonları içerisinde bakıldığında iki farklı organizmanın tasarım sürecinde kullanılabilirliği ele alınmıştır. Bu organizmalar; armadillo ve tespih böceğidir (Şekil 1).

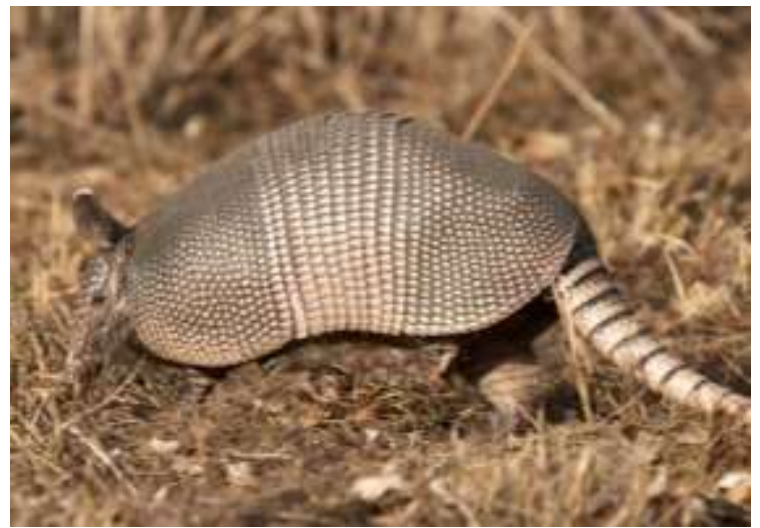

(a)

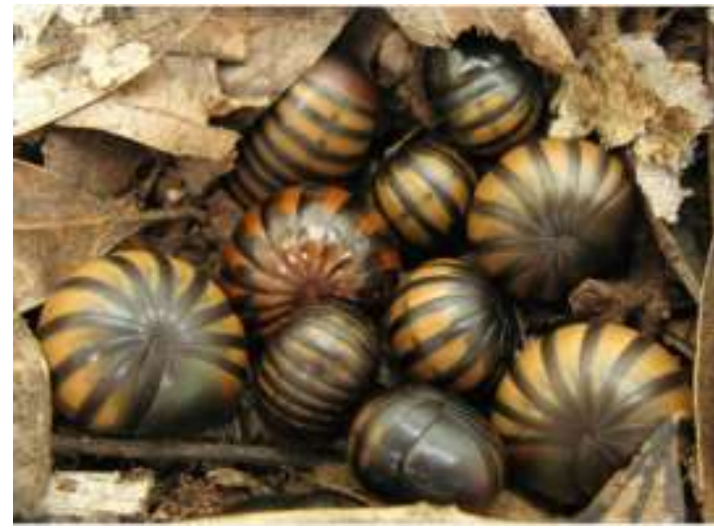

(b)

Şekil 1. İlham alınan organizmalar a) Armadillo; b) Tespih böceği [29]

$\mathrm{Bu}$ organizmalardan tespih böceği, eklemli iskeletlerini bir topun içine yuvarlayarak kendilerini avcılardan korumaktadır. Sert dış iskeleti, bir topun içine yuvarlanarak kafasını ve çok sayıdaki bacağını kaplamaktadır. Top şeklinde yuvarlanmış hali ile daha büyük bir hacme sahip olması sebebiyle avcıların daha büyük bir ağza sahip olması gerekmektedir [29]. Armadillo ise tespih böceği ile benzer bir stratejide bir top şeklinde yuvarlanarak ve yüzey alanlarını azaltarak kendilerini yırtıcılardan korumaktadırlar. Bir topun içine yuvarlanması basit ama etkili bir savunma şeklidir. Tüm savunmasız ve hayati organlar ve uzuvlar, koruyucu kılıfın içine sokularak yırtıcılara karşı sinir bozucu bir top oyunu sunulmaktadır [29]. Tespih böceğinin biyomimetik sınıflandırması Tablo 1'de verilmiştir.

Tablo 1. Tespih böceği biyomimetik sınıflandırması

\begin{tabular}{|c|c|c|c|}
\hline Organizma & Zorluk & Strateji & Fonksiyon \\
\hline Organizma nedir? & $\begin{array}{l}\text { Tespih böceği hangi } \\
\text { zorluğa } \\
\text { vermektedir? }\end{array}$ & $\begin{array}{l}\text { Tespih böceği bu } \\
\text { zorluğa nas1l karş1l1k } \\
\text { vermektedir? }\end{array}$ & $\begin{array}{l}\text { Tespih böceği } \\
\text { neden bu stratejiyi } \\
\text { uygulama ihtiyacı } \\
\text { duyar? }\end{array}$ \\
\hline $\begin{array}{l}\text { Tespih böcekleri doğada } \\
\text { yaşar }\end{array}$ & $\begin{array}{lr}\text { Savunmasız ve } & \text { hayati } \\
\text { organları } & \text { yırtıcı } \\
\text { hayvanlardan } & \\
\text { korumak } & \end{array}$ & $\begin{array}{l}\text { Eklemli yapıdaki sert } \\
\text { dış iskeleti ile top } \\
\text { şeklinde yuvarlanarak } \\
\text { kafasını ve çok sayıdaki } \\
\text { bacağını kılıfta korur. }\end{array}$ & $\begin{array}{l}\text { Avcılara karş1 } \\
\text { kendini korumak }\end{array}$ \\
\hline
\end{tabular}




\subsection{Tasarım Stratejisi}

Bu çalışmada, tespih böceğinin sert dış iskeletinin katlanarak bir top haline gelmesi prensibinden esinlenilerek katlanabilir, yüksekliği ayarlanabilir ve çok fonksiyonlu bir yürüteç tasarlanmıştır. Tespih böceğinin dış yapısı ile benzer özellikte modüler bir yürütecin, modüllerinin farklı şekillerde yuvarlanması ile farklı fonksiyonlar elde edilebilmektedir. Bu süreçte, doğadaki organizmadan form olarak esinlenilmiştir. Esinlenilen strateji aynı zamanda tespih böceğinin yaşam prensibi olarak değerlendirilmiştir.

Biyomimikri ile ürün geliştirme sürecinde kullanılan tasarım stratejilerinden biyolojiden yaratıcılığa yaklaşımıyla öncelikle doğada bulunan bir organizmanın (tespih böceği) hayatta kalma prensibinin hangi üründe kullanılabileceği belirlenmiştir. Daha sonra karar verilen üründe organizmanın hayatta kalma prensibinin hangi amaçla kullanılacağı değerlendirilmiştir. Son aşamada ise ürünün kapsamına karar verilerek tasarım stratejisi aşamaları tamamlanmıştır.

Tasarım eylemi ile bir tasarımcı öncelikle doğadaki modelleri keşfederek tanımlama getirmeli, benzetmelerde bulunarak fikirleri tasarıma entegre etmelidir [30]. Tasarım eylemi aşamaları; organizmanın keşfi, beyin firtınası, benzetme yapmak, değerlendirme yapmak, tanımlamak, belirlemek ve verilerin birleştirilmesi şeklindedir (Şekil 2.a). Tasarım eylemi aşamalarının tamamlanması sürecinde ise yaşam prensiplerinden faydalanılmaktadır [31]. Bu prensipler arasında; değişime adapte olma, uyum sağlama ve sorumlu olma, kaynakların verimli kullanımı, gelişme büyüme ile adapte olma bulunmaktadır (Şekil 2.b).

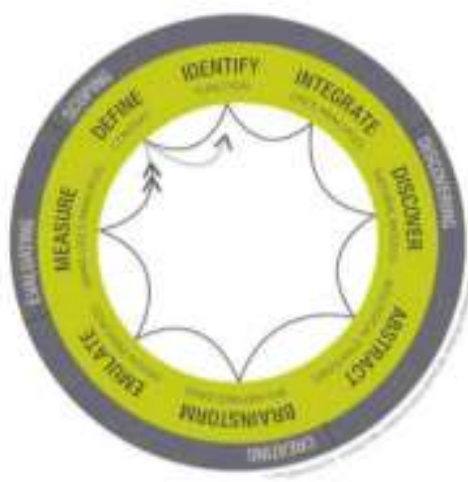

(a)

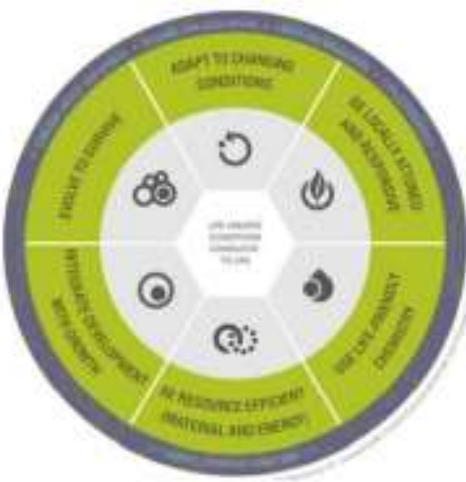

(b)

Şekil 2. Tasarım stratejisi a) Tasarım eylemi; b) Yaşam prensipleri [32]

Bu çalışmada tasarım stratejisi ile organizmanın belirlenmesi, değerlendirilmesi ve kapsamına karar verilmesi sürecinde biyomimikri tasarım eylemi aşamalarından yararlanılmıştır. Yürüteç tasarımının tasarım eylemi aşamaları Tablo 2'de verilmiştir.

Tablo 2. Yürüteç tasarımı tasarım eylemi

\begin{tabular}{lll}
\hline 1.Keşif & $\begin{array}{l}\text { Tespih böceklerinin eklemli dış iskeleti sayesinde top } \\
\text { Doğal modeller }\end{array}$ & şeklinde yuvarlanabildiği keşfedilmiştir. \\
\hline 2. Beyin fırtınası & Keşfedilen organizmanın yürüteç tasarımına nasıl \\
Biyolojiden esinlenen fikirler & yansıtılacağıyla ilgili beyin firtınası yapılmıştır. \\
\hline 3. Benzetme & $\begin{array}{l}\text { Tespih böceklerinin dış iskelet yapısına benzetilerek } \\
\text { Tasarım prensipleri }\end{array}$ & Tatlanabilen bir yürüteç tasarlanmıştır. \\
\hline 4. Ölçme & $\begin{array}{l}\text { Tasanan yürütecin birçok fonksiyona sahip olması, } \\
\text { Yaşam prensiplerini kullanarak }\end{array}$ & $\begin{array}{l}\text { ihtiyaçlar doğrultusunda farklı yürüteç satın alınmasını } \\
\text { engelleyebilecektir. }\end{array}$ \\
\hline
\end{tabular}


Yürüteç tasarımının belirlenen tasarım eylemlerine uygun olarak geliştirilen yaşam prensipleri Tablo 3'te verilmiştir. Tasarım eylemi ve yaşam prensiplerinin değerlendirilmesi sonucu tespih böceğinin kendi içine top şeklinde yuvarlanarak dış yüzey hacmini azalttığı tespit edilmiştir. Tespih böceğinin eklemli dış iskelet yapısından esinlenilerek yürütecin dış kabuğu oluşturulmuştur.

Tablo 3. Yürüteç tasarımı yaşam prensipleri

\begin{tabular}{ll}
\hline 1. Değişime Adapte OI & Mevcut yürüteçlerin özellikleri ihtiyaç dâhilinde \\
Mevcut kullanıma Alternatif & kullanılabilecek şekilde geliştirilmiştir. Yürüteç \\
& kullanılmadı̆̆ anda tamamen katlanabilecektir. \\
\hline 2. Uyum Sağla ve Sorumlu Ol & Modüler bir şekilde katlanarak kullanılabilecek \\
Doğaya bakış & yürüteç tasarımının çözümü doğadaki tespih \\
& böceğinde bulunmuştur. \\
\hline 3. Kaynakların Verimli Olsun & Farklı özelliklerdeki yürüteçleri ayrı ayrı satın almak \\
Sürdürülebilir & yerine tek bir ürünün tüm ihtiyaçlar için kullanılması \\
& ön planda tutulmuştur. \\
\hline 4. Gelişime Büyüme ile Adapte OI & Endüstrideki ürünlere alternatif olabilecek yenilikçi \\
Endüstriye uyum & bir tasarım geliştirilmiştir. \\
\hline
\end{tabular}

\subsection{Konsept Oluşturma}

Mevcutta kullanılmakta olan yürüteçlerde farklı özellikler bulunmakla birlikte tamamen katlanma prensibine dayalı bir tasarım bulunmamaktadır. Biyomimetik yaklaşımı ile geliştirilen yürüteç tasarımında ihtiyaç anında farklı fonksiyonlar için kullanılabilecek özellikler oluşturulmuştur. Fikir aşamasında tespih böceğinden esinlenilmesi sebebiyle yürüteç kullanılmadığı durumda katlanarak kendi ambalajını oluşturabilecektir. Bu aşamada yapılan ilk eskiz modelleri ve 3B modeli Şekil 3 'te gösterilmiştir. Modüler yapıdaki yürüteç tasarımının katlanılarak ihtiyaç durumunda oturma birimi haline dönüşebilmesi planlanmıştır.

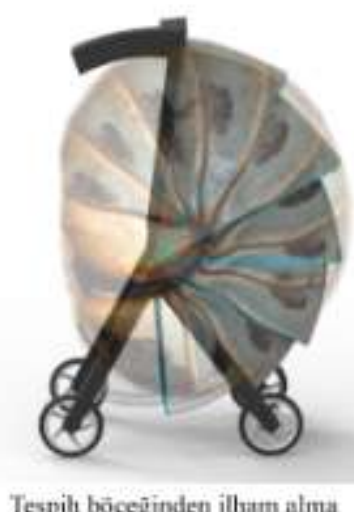

Şekil 3. İlk tasarım fikri görseli

İlk tasarım fikrinin oluşturulmasından sonra kullanılacak olan mekanizmanın belirlenmesi, yürütecin hangi malzeme ile üretileceği gibi detaylı bilgiler üzerine yapılan araştırmalar sonucu plastik bir iskelet sistemi ve bu iskelete gerdirilmiş olan su geçirmez kumaş kullanımı uygun görülmüştür. Modüler prensipten yararlanılarak yürüteç fonksiyonları arttırılmıştır. Bireyin yorulduğunda dinlenebilmesi için oluşturulan oturma birimi dışında, taşınan eşyaların yürüteci kullanan kişinin dengesini bozacağı düşünülerek tasarıma depolama/taşıma birimleri eklenmiştir. $\mathrm{Bu}$ birimlerden biri yürütecin alt kısmında, açı durumunda ve kolay ulaşılabilir durumdayken, diğer birim kapalı alanda ve daha büyük hacme sahiptir. Ayrıca iskeletin farklı açılarda 
döndürülmesi ile oturma birimi sırtlığının açısı ayarlanabilmektedir. Böylece, yürüteci kullanan kişi dik veya daha eğik pozisyonlarda oturabilecektir. Bu fikirlerin yansıtıldığ ve 3B modeli Şekil 4'te verilmiştir.
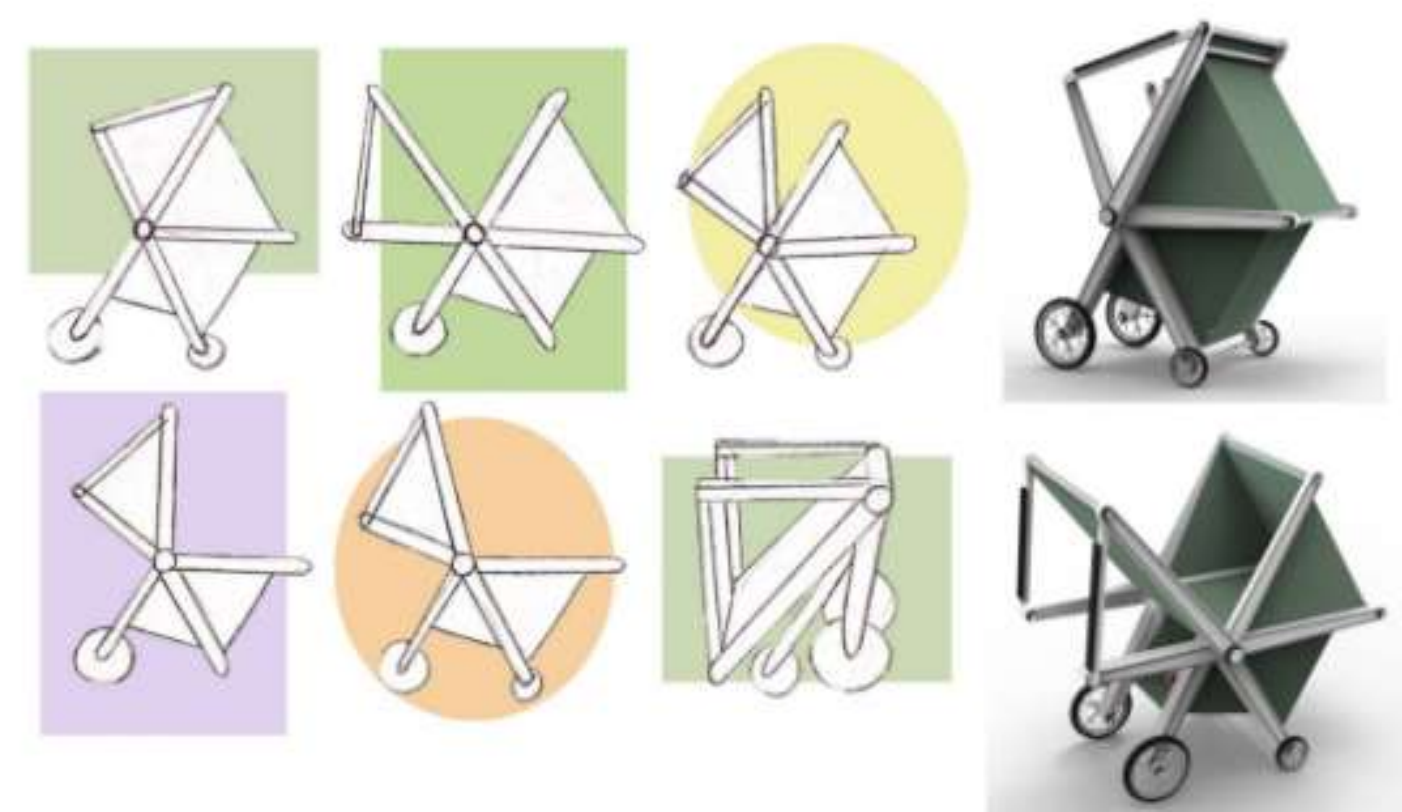

Şekil 4. İkinci tasarım fikri görseli

İkinci tasarım fikrinin oluşturulmasından sonra iskelet modüllerinin istenilen açılarda katlanmasını sağlayacak bir mekanizmanın, tasarımın esnekliğini ve kullanım kolaylığını olumsuz yönde etkileyeceği düşünülerek konsept üzerinde değişikliğe gidilmiştir. Karar verilen son tasarımda, modüller katlanmadan tamamıyla birbiri içerisine geçerek döndürülebilecektir.

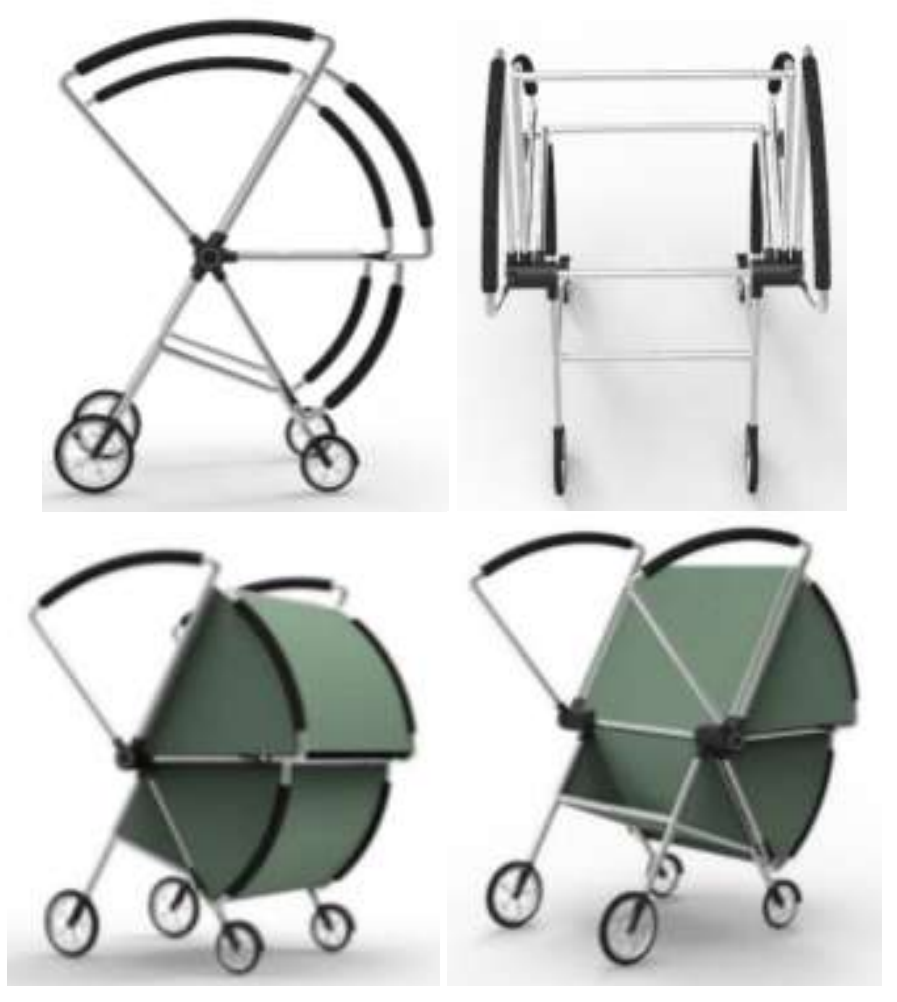

Şekil 5. Nihai tasarım fikri görseli 
$\mathrm{Bu}$ durum, hem mekanizma açısından avantaj sağlayacak hem de biyomimetik olarak esinlenilmiş olan tespih böceğinin katlanma prensibi ile daha çok benzeşecektir. Nihai tasarımın ana iskeleti alüminyum profiller ile oluşturulmuş ve tek bir mekanizma etrafında kademeli olarak döndürülebilecektir. Nihai tasarım fikrine ait görseller Şekil 5'te gösterilmiştir.

Yürüteç tasarımı, modüler yapısı sebebiyle çok fonksiyonlu kullanıma imkân vermektedir. Bu fonksiyonların sağlanmasını için modüllerin katlanma biçimleri Şekil 6'da gösterilmiştir.

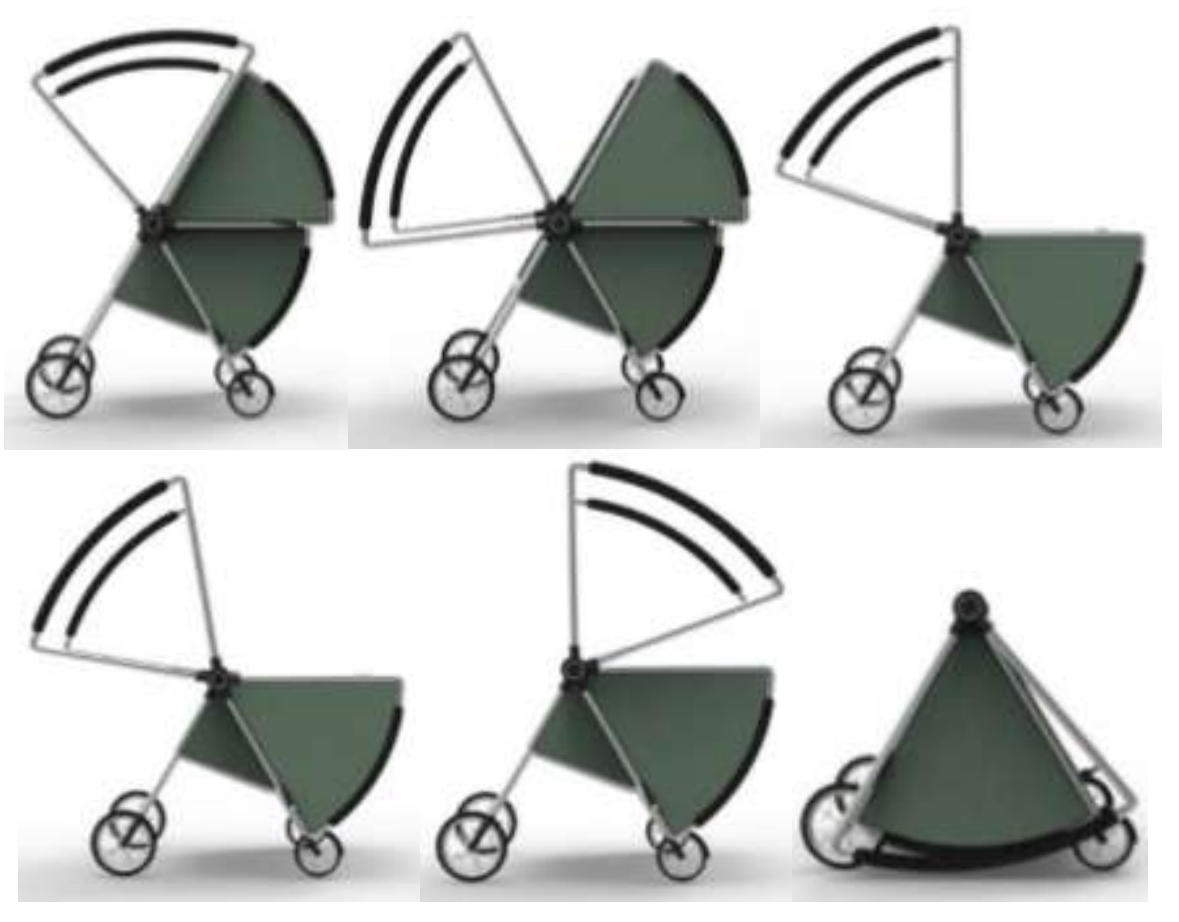

Şekil 6. Modüler yürüteç tasarımının farklı fonksiyonlardaki durumu

\section{Yürüteç Tasarımının Ergonomik Risk Değerlendirmesi}

Ürün tasarımı ve geliştirilmesinde, ürünün kullanımı sırasında meydana gelebilecek tüm risklerin minimize edilmesi amacıyla ergonomi biliminden faydalanılmaktadır. Belirlenen kullanıcı kitlesinin antropometrik ölçülerine uygun olarak tasarım üzerinde iyileştirmeler yapılmaktadır. Antropometri ile ergonomik analiz uygulamalarında kullanılacak olan insan vücut ölçüleri belirlenmektedir. Üretim öncesi süreçlerde gerçekleştirilen ergonomik analiz uygulamaları ile kullanıcılarda meydana gelebilecek fiziksel ve psikolojik problemleri önüne geçilebilmektedir [33-36].

Ergonomik analiz yazılımları ile ürünün gerçek kullanım senaryosu CAD ortamına simüle edilmektedir. DHM yöntemi ile CAD yazılımlarında üç boyutlu modeli oluşturulan ürünlere dijital insan modelleri belirlenen antropometrik ölçü ve pozisyonlarda yerleştirilmektedir. Böylece, üretim öncesi süreçlerde ergonomik analiz işlemleri gerçekleştirilerek gereksiz prototip üretimlerinden kurtularak maliyet düşürülmektedir [37-39].

DHM kullanılarak ergonomik analizlerin gerçekleştirildiği farklı değerlendirme yöntemleri bulunmaktadır. Bunlardan bazıları; RULA, REBA, Ovako Çalışma Analiz Sistemi (Ovako Working Analysis System - OWAS), NIOSH Kaldırma Denklemi (National Institute for Occupational Safety and Health - NIOSH) ve Lumbar Hareket Monitörü (Lumbar Motion Monitor - LMM) şeklindedir [40-42]. 
$\mathrm{Bu}$ çalışmada, tasarım süreci bahsedilen yürüteç tasarımının ergonomik değerlendirilmesi CATIA V5 yazılımı ile REBA ve RULA yöntemleri kullanılarak gerçekleştirilmiştir. REBA'da DHM kullanılarak vücudun tüm bölgelerindeki fleksiyon ve ekstansiyon açlları ile rotasyon, esneme,

Tablo 4. REBA analizi [43, 44]

\begin{tabular}{|c|c|c|c|c|}
\hline \multirow{3}{*}{$\begin{array}{l}\text { BOYUN SKOR } \\
\text { TABLOSU }\end{array}$} & HAREKET & SKOR & \multirow[t]{3}{*}{ SKOR DEĞİşìi } & \multirow{3}{*}{$\frac{1}{7} y^{(2)}$} \\
\hline & $0^{\circ}-20^{\circ}$ FLEKSIYYON & 1 & & \\
\hline & $\begin{array}{c}>20^{\circ} \text { FLEKSIYYON VEYA } \\
\text { EKSTANSIYON }\end{array}$ & 2 & & \\
\hline \multirow{5}{*}{$\begin{array}{l}\text { GÖVDE SKOR } \\
\text { TABLOSU }\end{array}$} & HAREKET & SKOR & SKOR DEĞİŞİMI & \multirow{5}{*}{ (3) $\stackrel{0}{0}$} \\
\hline & DİK & 1 & \multirow[t]{4}{*}{$\begin{array}{l}\text { YANA ESNEME VEYA } \\
\text { DÖNME VARSA +1 }\end{array}$} & \\
\hline & $\begin{array}{c}0^{\circ}-20^{\circ} \text { FLEKSIYYON } \\
0^{\circ}-20^{\circ} \text { EKSTANSIYON }\end{array}$ & 2 & & \\
\hline & $\begin{array}{l}20^{\circ}-60^{\circ} \text { FLEKSIYON } \\
>20^{\circ} \text { EKSTANSIYON }\end{array}$ & 3 & & \\
\hline & $>60^{\circ}$ FLEKSIYON & 4 & & \\
\hline \multirow{3}{*}{$\begin{array}{l}\text { BACAK SKOR } \\
\text { TABLOSU }\end{array}$} & HAREKET & SKOR & SKOR DEĞiş̧iMI & \multirow{3}{*}{ 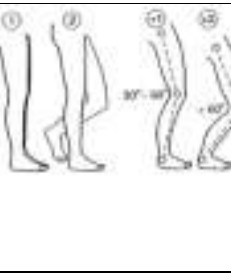 } \\
\hline & $\begin{array}{c}\text { BİLATERAL (IKİ TARAFLI) } \\
\text { AĞIRLIK TASSIMA, YÜRÜME } \\
\text { VEYA OTURMA }\end{array}$ & 1 & $\begin{array}{c}\text { DİZ(LER)DE } 30^{\circ}-60^{\circ} \\
\text { ARASI FLEKSIYON +1 }\end{array}$ & \\
\hline & $\begin{array}{l}\text { UNILATERAL (TEK TARAFLI) } \\
\text { AĞIRLIK TASSIMA VEYA } \\
\text { SABİT OLMAYAN DURUŞ }\end{array}$ & 2 & $\begin{array}{c}\text { DİZ(LER)DE }>60^{\circ} \\
\text { FLEKSIYON (OTURMA } \\
\text { HARIÇ) }+\mathbf{2} \\
\end{array}$ & \\
\hline \multirow{3}{*}{$\begin{array}{l}\text { ALT KOLLAR AÇI- } \\
\text { SKOR TABLOSU }\end{array}$} & HAREKET & & SKOR & \multirow{3}{*}{$\int_{0}^{\frac{2}{3}}=$} \\
\hline & $60^{\circ}-100^{\circ}$ FLEKSIYON & & 1 & \\
\hline & $\begin{array}{c}<60^{\circ} \text { FLEKSIYYON VEYA } \\
>100^{\circ} \text { FLEKSIYON }\end{array}$ & & 2 & \\
\hline \multirow{5}{*}{$\begin{array}{l}\text { ÜST KOLLAR AÇI- } \\
\text { SKOR TABLOSU }\end{array}$} & HAREKET & SKOR & SKOR DEĞIşìiMI & \multirow{5}{*}{$2 x_{0} 00$} \\
\hline & $\begin{array}{c}20^{\circ} \text { FLEKSIYON - } \\
20^{\circ} \text { EKSTANSIYON }\end{array}$ & 1 & \multirow{4}{*}{$\begin{array}{l}\text { KOLDA: } \\
\text { ABDÜKSIYON VARSA } \\
\text { ROTASYON VARSA } \\
+1 \\
\text { OMUZ YÜKSELMIŞSE } \\
+1 \\
\text { KOLUN DURUŞUNDA } \\
\text { YER ÇEKIMI DESTEĞİ } \\
\text { ETKILIYSE } \\
-1 \\
\end{array}$} & \\
\hline & $\begin{array}{l}20^{\circ}-45^{\circ} \text { FLEKSIYON } \\
>20^{\circ} \text { EKSTANSIYON }\end{array}$ & 2 & & \\
\hline & $45^{\circ}-90^{\circ}$ FLEKSIYON & 3 & & \\
\hline & $>90^{\circ}$ FLEKSIYON & 4 & & \\
\hline \multirow{3}{*}{$\begin{array}{l}\text { BÍLEKLER AÇI- } \\
\text { SKOR TABLOSU }\end{array}$} & HAREKET & SKOR & SKOR DEĞIŞ̧iMI & \multirow{3}{*}{ 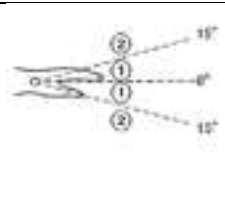 } \\
\hline & $\begin{array}{c}0^{\circ}-15^{\circ} \text { FLEKSIYON VEYA } \\
\text { EKSTANSIYON }\end{array}$ & 1 & \multirow{2}{*}{$\begin{array}{c}\text { BILEKLERDE YANA } \\
\text { ESNEME VEYA DÖNME } \\
\text { VARSA + } 1\end{array}$} & \\
\hline & $\begin{array}{c}>15^{\circ} \text { FLEKSIYON VEYA } \\
\text { EKSTANSIYON }\end{array}$ & 2 & & \\
\hline
\end{tabular}

abdüksiyon vb. gibi hareketleri dikkate alınarak bir değerlendirme gerçekleştirilmektedir. RULA'da ise DHM kullanılarak vücudun üst bölgesinde meydana gelen baskı ve gerilmelere göre bir değerlendirme yapılmaktadır [42].

\subsection{REBA Yöntemi}

REBA yöntemi ile vücudun bölümleri ve A ve B grupları şeklinde ayrı ayrı analiz edilerek REBA skoru elde edilmektedir. A grubunda bulunan bölümler boyun, gövde ve bacaklar iken, B grubunda 
alt-üst kollar ve bileklerdir. Kişinin duruş pozisyonuna göre bu bölgelerin ekstansiyon ve fleksiyon açılarına göre A ve B skorları elde edilmektedir. Ayrıca, vücudun ilgili bölümünde esneme, dönme, abdüksiyon gibi durumlar varsa ekstra puan eklenmektedir. Örneğin, belirlenen duruş pozisyonunda boyun bölgesindeki fleksiyon açısı $0^{\circ}-20^{\circ}$ arasındaysa bu bölüme ait skor 1'dir. Aynı zamanda yana esneme de söz konusu ise 1 puan daha eklenerek boyun bölgesi toplam skoru 2 olmaktadır. Bu süreçte, REBA yöntemine ait tablolardan faydalanılmaktadır (Tablo 4).

A skorunu elde etmek için öncelikle boyun, gövde ve bacakların ayrı ayrı skorlarının belirlenmesi gerekmektedir. B skoru için de aynı şekilde alt-üst kollar ve bileklerin skorları belirlenmelidir. A ve B skorlarının elde edilmesi için başka bir REBA yöntemi tablosundan faydalanılmaktadır (Tablo 5). $\mathrm{Bu}$ tabloda, ilgili bölümlere ait puanlar işaretlendikten sonra oluşan kesişim kümesi A ve B skorlarını vermektedir. Elde edilen A ve B skorları, C skoru tablosunda kesiştirilerek nihai skora (C skoru) ulaşılmaktadır.

Tablo 5. REBA skorunun belirlenmesi $[43,44]$

A Skoru

\begin{tabular}{|c|c|c|c|c|c|c|c|c|c|c|c|c|c|}
\hline & & \multicolumn{12}{|c|}{ BOYUN } \\
\hline & & \multicolumn{4}{|c|}{$\begin{array}{c}1 \\
\text { BACAKLAR }\end{array}$} & \multicolumn{4}{|c|}{$\begin{array}{c}2 \\
\text { BACAKLAR }\end{array}$} & \multicolumn{4}{|c|}{$\begin{array}{c}3 \\
\text { BACAKLAR }\end{array}$} \\
\hline \multirow{6}{*}{ GÖVDE } & & 1 & 2 & 3 & 4 & 1 & 2 & 3 & 4 & 1 & 2 & 3 & 4 \\
\hline & 1 & 1 & 2 & 3 & 4 & 1 & 2 & 3 & 4 & 3 & 3 & 5 & 6 \\
\hline & 2 & 2 & 3 & 4 & 5 & 3 & 4 & 5 & 6 & 4 & 5 & 6 & 7 \\
\hline & 3 & 2 & 4 & 5 & 6 & 4 & 5 & 6 & 7 & 5 & 6 & 7 & 8 \\
\hline & 4 & 3 & 5 & 6 & 7 & 5 & 6 & 7 & 8 & 6 & 7 & 8 & 9 \\
\hline & 5 & 4 & 6 & 7 & 8 & 6 & 7 & 8 & 9 & 7 & 8 & 9 & 9 \\
\hline
\end{tabular}

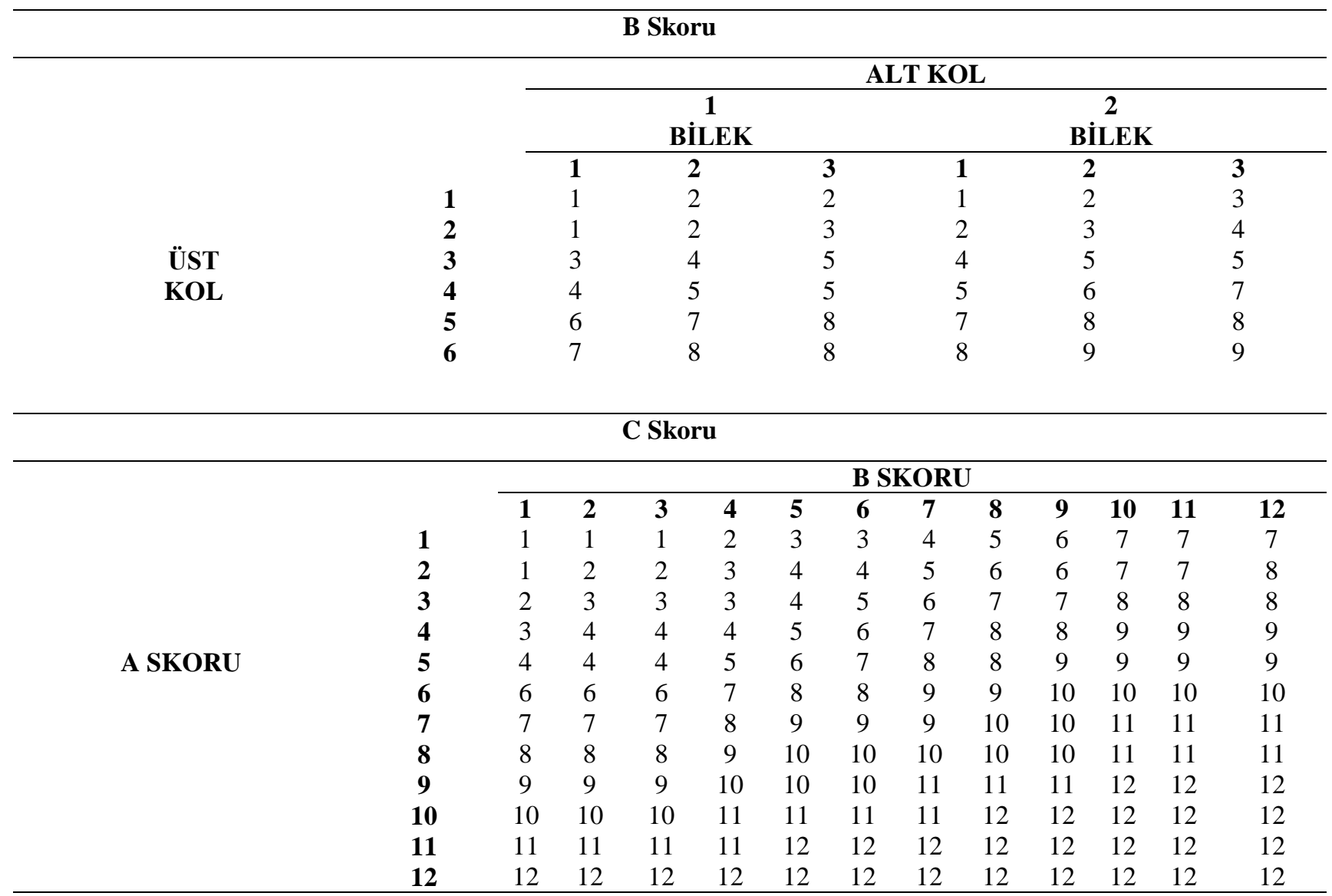


REBA skorunun tespit edilebilmesi için $\mathrm{C}$ skoruna aktivite yoğunluk tablosundan elde edilen toplam skor eklenmektedir (Tablo 6). Bu tabloda, duruş pozisyonu veya hareket esnasında kişiye gelen yük durumu, eğer bir tutma kolu varsa tutuş planı ve aktivitenin gerçekleştirilme şekline ait skorlar bulunmaktadır.

Tablo 6. Aktivite yoğunluk tablosu $[43,44]$

Taşınan Yük- Skor Tablosu

\begin{tabular}{lc}
\hline Yük/Kuvvet & SKOR \\
\hline$<5 \mathrm{~kg}$ & 0 \\
$5-10 \mathrm{~kg}$ & 1 \\
$>10 \mathrm{~kg}$ & 2 \\
Ani veya hızlı kuvvet artışı & +1 \\
\hline
\end{tabular}

Tutuș Planı - Kavrama - Skor Tablosu

\begin{tabular}{llc}
\hline Derece & Açılama & SKOR \\
\hline İyi & İyi bir tutma kolu ve orta şiddette kavrama gücü & 0 \\
Uygun & El tutuşu uygun fakat ideal değil veya vücudun başka bir bölgesi ile & 1 \\
& kavrama uygun & 2 \\
Kötü & El tutuşu uygun olmamasına rağmen mümkün & 3 \\
Uygun & Zor ve güvenli olmayan tutuş, tutma kolu yok & \\
değil & Vücudun başka bir bölgesi kullanılarak tutuş uygun değil
\end{tabular}

\section{Aktivite Skoru Tablosu}

\begin{tabular}{lc}
\hline Aktivite & SKOR \\
\hline Bir veya daha fazla vücut bölgesi sabit (Örn; 1 dakikadan uzun süre tutma) & +1 \\
Kısa aralıklarla tekrar eden işler (Örn; 1 dakikada 4'ten fazla tekrar eden iş, & +1 \\
yürüme hariç) & \\
$\begin{array}{l}\text { Yapılan iş, duruşta hızlı ve büyük değişikliğe neden oluyorsa veya sabit olmayan } \\
\text { zeminde çalış1lyyorsa }\end{array}$ & +1 \\
\hline
\end{tabular}

Fonksiyonel yürüteç tasarımının REBA yöntemi ile ergonomik risk değerlendirmesi için CATIA V5 programında ortalama antropometrik ölçülere sahip bir dijital insan modeli oluşturularak uygun duruş pozisyonlarında yerleştirilmiştir. Öncelikle yürüme pozisyonundaki insan modelinin REBA skorunun belirlenmesi için boyun, gövde, bacak, kol ve bileklere ait skorlar Tablo 4'te yer alan bilgilere göre belirlenmiștir (Şekil 7). Gövdenin dik pozisyonda olması ve yana esneme ve dönme hareketi olmaması sebebiyle skoru 1'dir. Boyun bölgesi fleksiyon açısı $0^{\circ}$ ve 1 puandır. Bacak bölgesinin skoru, yürüme fonksiyonu sebebiyle 1'dir. Tespit edilen bu puanlar A skoru tablosunda (Tablo 5) kesiştirilerek A skoru 1 olarak belirlenmiştir.

İkinci olarak B grubunda bulunan bölgelerden biri olan alt kol fleksiyon açısının $69^{\circ}$ olması sebebiyle skoru 2'dir. Üst kolda abdüksiyon yani yatay eksende vücuda yaklaşma ya da vücuttan uzaklaşma hareketi olması sebebiyle toplam skor 1 olarak belirlenmiştir. Bilek ekstansiyon açısı $5,95^{\circ}$ ve ayrıca yana esneme hareketi olması sebebiyle toplam skoru 2'dir. Bu duruma göre B skoru tablosundaki eşleştirmelere göre B skoru 2 olarak tespit edilmiştir. A ve B skorlarının çaprazlanması ile de C skoru 1 olarak elde edilmiştir.

Aktivite yoğunluk tablosuna göre ise yürüteç tasarımının ayakta kullanımı sırasında tutuş-kavrama skoru, iyi bir tutma kolu ve orta şiddette kavrama gücü olması sebebiyle 0'dır. 5 kilogramın üzerinde doğrudan bir taşıma yoktur ve yürüme aktivitesi gerçekleştirilmektedir. Bu sebeple, Tablo 
6'dan elde edilen verilere göre Aktive Yoğunluk Puanı 0'dır. REBA skoru, C skoru ve Aktivite Yoğunluk skorlarının toplamı sonucunda 1'dir.

Yürüme pozisyonundaki insan modelinin REBA skorunun belirlenmesinin ardından oturma pozisyonu REBA skoru için öncelikle gövdenin ekstansiyon açısı 5,25 ${ }^{\circ}$ olarak tespit edilmiş ve skoru 2'dir. Yana doğru esneme veya dönem hareketi yoktur. Boyun bölgesinde açı sıfırdır ve skor $1^{\prime}$ 'dir. Bacaklarda fleksiyon açısı $88^{\circ}$ ve skor 1'dir (Şekil 8). Tablo 5'deki bilgilere göre A skoru 2'dir.

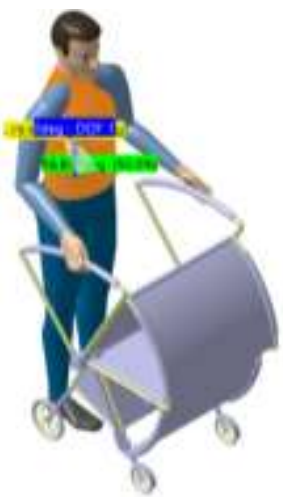

(a)

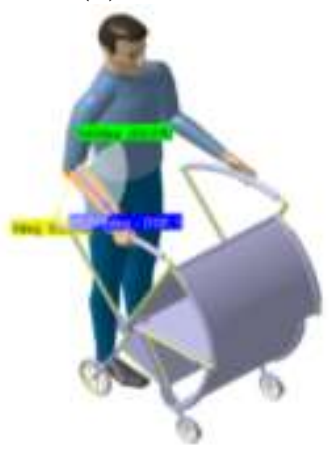

(d)

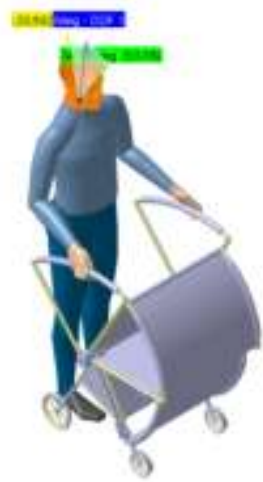

(b)

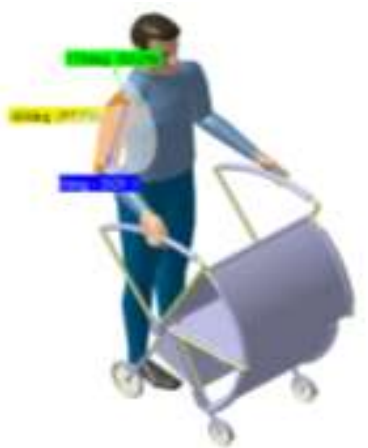

(e)

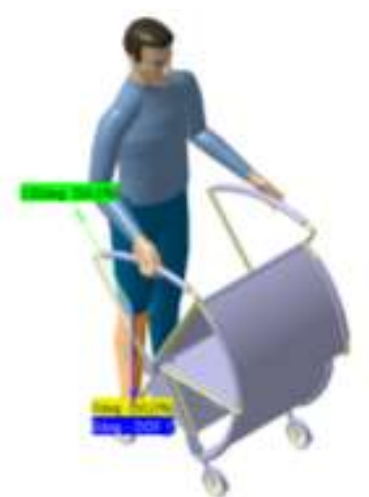

(c)

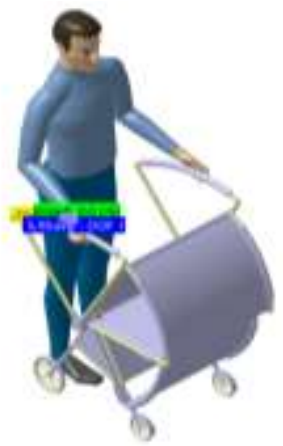

(f)

Şekil 7. Yürüme Pozisyonu Fleksiyon-Ekstansiyon Açıları a) Gövde; b) Boyun; c) Bacak;

d) Alt kol; e) Üst kol; f) Bilek

Yürüme pozisyonu B skorunun tespiti için belirlenen alt ve üst kol ve bileklerin fleksiyonekstansiyon açısı değerlerine göre her üç bölgenin de skoru 1'dir. B skoru değeri ise 1'dir. Bu duruma göre yürüme pozisyonu $\mathrm{C}$ skoru değeri 1'dir. Aktivite yoğunluk skoru ise 0'dir ve nihai REBA skoru 1'dir.

Tablo 7. Yürüteç tasarımı REBA Skoru

\begin{tabular}{lcc}
\hline \multicolumn{1}{c}{ Pozisyon } & Yürüme & Oturma \\
\hline Gövde & 1 & 2 \\
Boyun & 1 & 1 \\
Bacak & 1 & 1 \\
A Skoru & 1 & 2 \\
Alt Kol & 2 & 1 \\
Üst Kol & 1 & 1 \\
Bilek & 2 & 1 \\
B Skoru & 2 & 1 \\
C Skoru & 1 & 1 \\
Aktivite Yoğunluğu & 0 & 0 \\
\hline REBA Skoru & 1 & 1
\end{tabular}


Yürüteç tasarımının yürüme ve oturma pozisyonlarına ait REBA yöntemi ile ergonomik risk değerlendirmesine ait belirlenen tüm skorlar Tablo 7'de gösterilmiştir. Yürüme ve oturma pozisyonlarının her ikisinin de REBA skoru 1'dir.

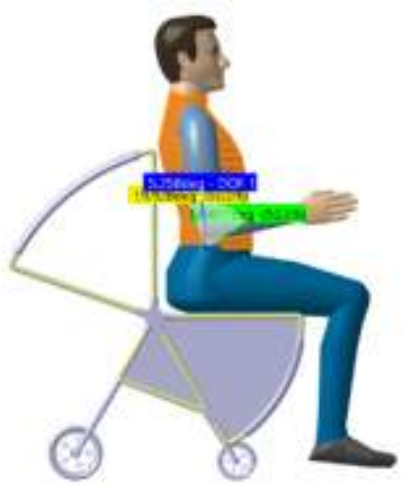

(a)

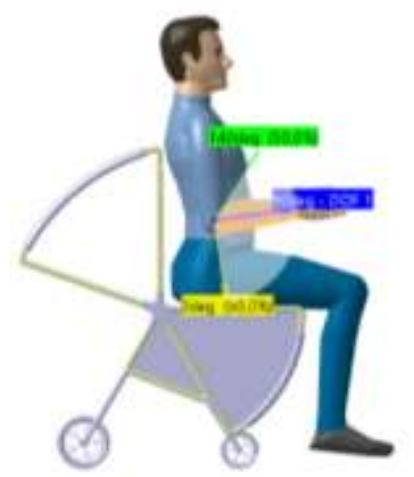

(d)

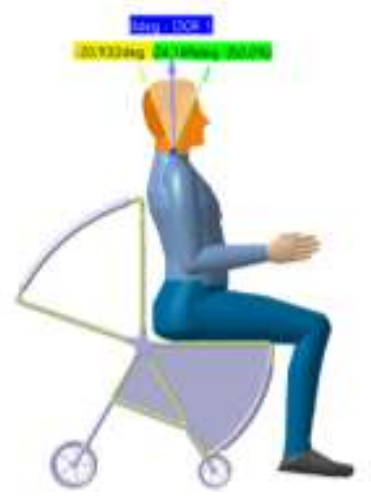

(b)

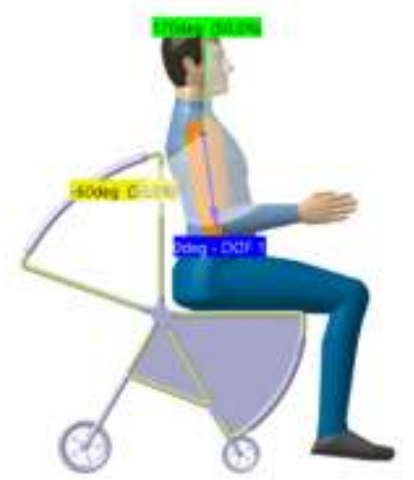

(e)

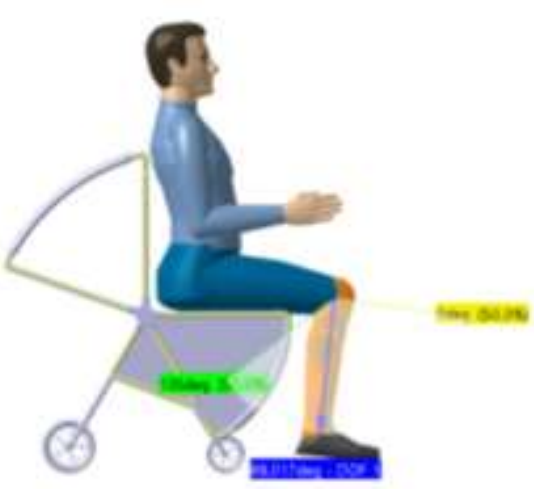

(c)

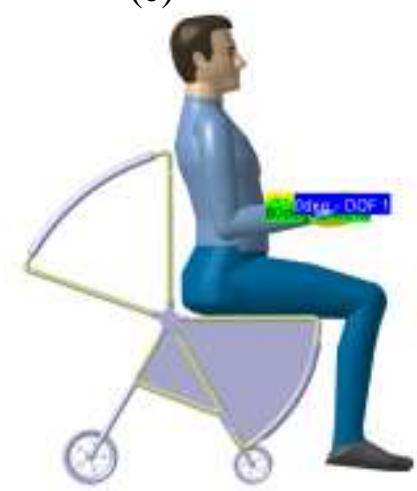

(f)

Şekil 8. Oturma Pozisyonu Fleksiyon-Ekstansiyon Açıları a) Gövde, b) Boyun; c) Bacak; d) Alt kol; e) Üst kol; f) Bilek

REBA yöntemi ile elde edilen skorlara göre risk seviyeleri Tablo 8'de verilmiştir. Yürüteç tasarımının her iki pozisyonda kullanımına ait REBA skoru 1 olarak belirlenmiştir ve bu değer, göz ardı edilebilecek seviyede olarak tespit edilmiştir.

Tablo 8. REBA Risk Derecelendirmesi - Karar Tablosu [42]

\begin{tabular}{llll}
\hline Derece & Reba skoru & Risk seviyesi & Önlem \\
\hline 0 & 1 & Ihmal edilebilir & Gerekli değil \\
1 & $2-3$ & Düşük & Gerekli olabilir \\
2 & $4-7$ & Orta & Gerekli \\
3 & $8-10$ & Yüksek & Kisa zaman içinde gerekli \\
4 & $11-15$ & Çok yüksek & Hemen gerekli \\
\hline
\end{tabular}

\subsection{RULA Yöntemi}

RULA yönteminde DHM kullanılarak ergonomik risk değerlendirmesi yapılmaktadır. Bu yöntem ile ön kol, üst kol, bilek, boyun ve gövde gibi vücudun üst bölümlerine ait ergonomik analiz gerçekleştirilmektedir. RULA sonucunda elde edilen tabloda vücudun bu bölümlerine ait farklı puan ve renklendirmeler verilmektedir (Tablo 9). Puan 1'den 6'ya doğru yükseldikçe ergonomik risk değeri artmaktadır. Örneğin, bilekler için 1-4 arasında bir final skoru belirlenmektedir. Bu 
değerler sırasıyla yeşil, sarı turuncu ve kırmızı renklerle temsil edilerek risk değerinin arttığını göstermektedir.

Yürüteç tasarımının RULA yöntemi ergonomik risk değerlendirilmesi için REBA yönteminde olduğu gibi yürüme ve oturma pozisyonları dikkate alınmıştır. CATIA V5 programının RULA aracı kullanılarak dijital insan modelleri uygun pozisyonlarda yürüteç tasarımı üzerine yerleştirilmiştir. Yürüme pozisyonu RULA sonuçları Şekil 9'da verilmiştir. RULA final skoru 3 ve sarı renk ile gösterilmiştir.

Tablo 9. RULA analizi puan tablosu değerlendirmesi [42, 45]

\begin{tabular}{l|c|c|c|c|c|c|c}
\hline Vücut bölümü & Skor & $\mathbf{1}$ & $\mathbf{2}$ & $\mathbf{3}$ & $\mathbf{4}$ & $\mathbf{5}$ & $\mathbf{6}$ \\
\hline Üst kol & $1-6$ & & & & & & \\
\hline Önkol & $1-3$ & & & & & & \\
\hline Bilek & $1-4$ & & & & & & \\
\hline Bilek bükümü & $1-2$ & & & & & & \\
\hline Boyun & $1-6$ & & & & & & \\
\hline Gövde & $1-6$ & & & & & & \\
\hline
\end{tabular}

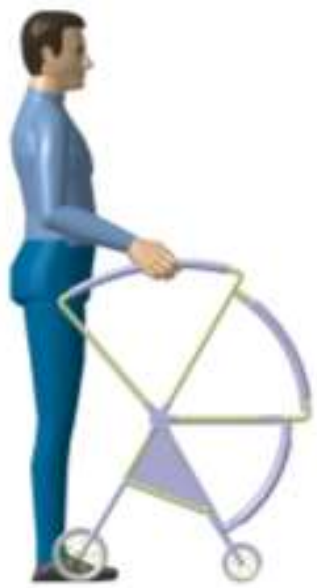

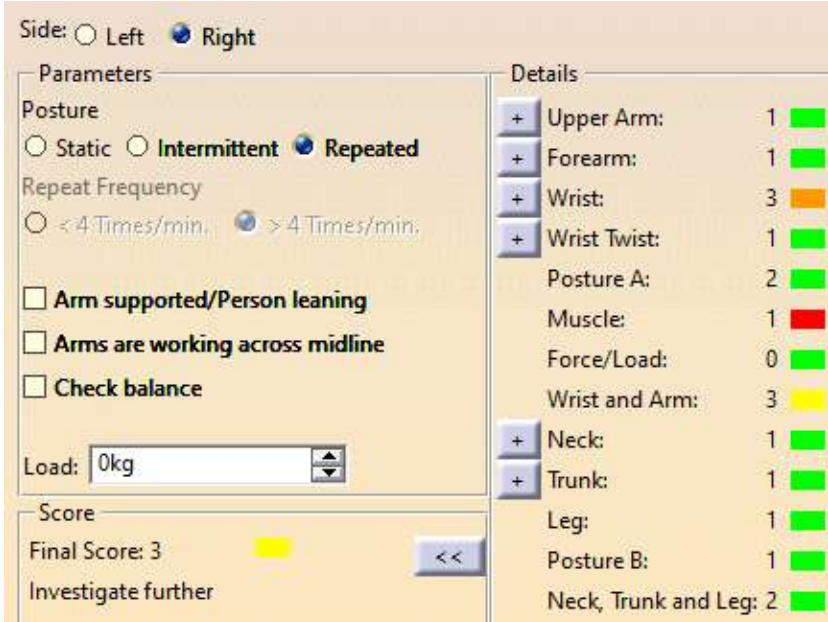

Şekil 9. Dijital insan modeli yürüme pozisyonu RULA sonucu

Dijital insan modelinin oturma pozisyonuna ait RULA sonuçları Şekil 10'da verilmiştir. RULA final skoru 2 ve yeşil renk ile gösterilmiştir.
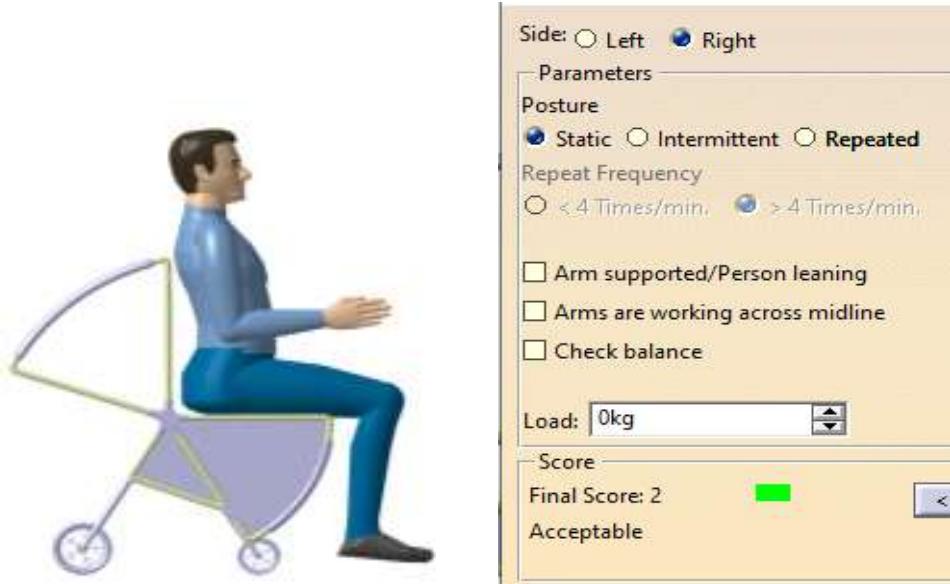

\begin{tabular}{|c|c|c|}
\hline \multicolumn{3}{|c|}{ Details } \\
\hline+ & Upper Arm: & $1=$ \\
\hline+ & Forearm: & $1=$ \\
\hline+ & Wrist: & $1=$ \\
\hline+ & Wrist Twist: & $1=$ \\
\hline & Posture A: & 1 \\
\hline & Muscle: & $1=$ \\
\hline & Force/Load: & $0=$ \\
\hline & Wrist and Arm: & 2 \\
\hline+ & Neck: & $1=$ \\
\hline+ & Trunk: & $1=$ \\
\hline & Leg: & 1 \\
\hline & Posture B: & $1=$ \\
\hline & Neck, Trunk a & 2 \\
\hline
\end{tabular}

Şekil 10. Dijital insan modeli oturma pozisyonu RULA sonucu 
RULA yöntemi sonucu elde edilen final skorları ve renk göstergelerinin risk faaliyeti karşıllı̆g Tablo 10'da verilmiştir. Buna göre, yürüteç tasarımının yürüme pozisyonunda kullanımına ait RULA ergonomik değerlendirmesi final skoru 3 ve sarı renk ile temsil edilmesi sebebiyle düşük bir risk seviyesine sahiptir. Tasarım üzerinde daha fazla araştırma yapılabilir. Yürüteç tasarımının oturma pozisyonunda kullanımının RULA final skoru ise 2 ve yeşil renk temsili ile ihmal edilebilir düzeyde bir risk değerine sahiptir.

Tablo 10. RULA tablosunun yorumlanmas1 $[42,46]$

\begin{tabular}{lll}
\hline RULA Final Skoru & Risk seviyesi & Faaliyet \\
\hline $1-2$ & İhmal edilebilir & $\begin{array}{l}\text { Kabul edilebilir } \\
\text { Daha fazla araştırma ve değişiklik } \\
\text { gerekebilir }\end{array}$ \\
Düşük & Araştırma ve yakında gerekli değișiklikler \\
$5-6$ & Orta & Soruşturma ve hemen gerekli değişiklikler \\
7
\end{tabular}

\section{Sonuçlar}

Alt ekstremite problemi olan dezavantajlı bireylerde, ortopedi hastalarında ve yürüme zorluğu çeken ileri yaştaki insanlarda dengeyi sağlayabilmek veya protez üzerine yüklenmemek amacıyla yürüteç kullanılmaktadır. Yürüteçler, baston kullanımına göre bireye daha fazla destek sağlamaktadır. Tasarlanan ürünün kapsamı alt ekstremite problemine sahip ve ileri yaştaki bireylerin hayat standardını yükseltmeye yönelik çok fonksiyonlu, ergonomik bir yürüteç tasarımıdır. $\mathrm{Bu}$ çalışma kapsamında, biyomimetik tabanlı modüler bir yürüteç tasarımı gerçekleştirilmiştir. Tasarımın modüler özelliği sayesinde ihtiyaç durumuna göre oturma birimi olması ve katlanabilmesi kullanıcılara kolaylık sağlamaktadır. Tasarımın ön kısmındaki taşıma birimi ile kullanıcının yürüyüş sırasında yanında bulundurması gereken eşyaları taşınabilmektedir. Yürüteç tasarımının 3B modelinin tamamlanmasının ardından ergonomik risk değerlendirmesi DHM kullanılarak gerçekleştirilmiştir. Yürüteç tasarımının yürüme ve oturma pozisyonlarındaki kullanımının ergonomik analizi için yöntem olarak REBA ve RULA tercih edilmiştir. Ortalama antropometrik verilere sahip bir dijital insan modelinin yürüme ve oturma pozisyonlarındaki REBA final skoru 1 olarak tespit edilmiştir. Bu sonuç, ergonomik risk değerinin ihmal edilebilir bir seviyede olduğunu belirtmektedir. Yürüteç tasarımının yürüme pozisyonunda kullanımının ergonomik değerlendirilmesi sürecindeki RULA final skoru 3 ve sarı renk ile temsil edildiği belirlenmiştir. $\mathrm{Bu}$ sonuç, düşük seviyede bir riskin bulunduğunu ve ileriki süreçlerde tasarım üzerinde iyileştirmelere ihtiyaç duyulabileceğini göstermektedir. Oturma pozisyonunun ergonomik açıdan değerlendirilmesinde ise RULA final skoru 2 ve yeşil renk ile gösterilmiştir. Bu durum, ergonomik açıdan oturma pozisyonunun göz ardı edilebilecek bir seviyede risk barındırdığını belirtmektedir.

\section{Yazar(lar)ın Katkıları}

NT, HB ve İş çalışmayı gerçekleştirdi ve makaleyi yazdı. Yazarlar makalenin son halini okudu ve onayladi.

\section{Çıkar Çatışması}

Yazarlar, çıkar çatışması olmadığını beyan eder.

\section{Kaynaklar}

[1]. Miller, D. B., O'callaghan, J. P. "Aging, stress and the hippocampus", Ageing Research Reviews, 2005, 4 (2): 123-140. 
[2]. Pierson, F. M., Fairchild, S, L. "Principles and techniques of patient care", Elsevier, Saunders, (2008).

[3]. İnternet: http://eczacininsesi.com/index.php?yon=medikal\&id=47. Erişim Tarihi: 02.01.2021.

[4]. İnternet:http://formedhealthcare.com/Tr/ortopedik_urunler/17/rehabilitasyon-urunleri/31/ yurumeye-yardimci-cihazlar. Erişim Tarihi: 02.01.2021.

[5]. Furman, J., S. Cass. "Vestibular disorders: a case study approach", Oxford University Press, USA, (2003).

[6]. İnternet: https://www.medikalportali.net/kanedyen-koltuk-degnegi-yurutec-rolator-nasilkullanilir/. Erişim Tarihi: 02.01.2021.

[7]. Çağatay, E., Yaz, M., Gökçe, H. "Upper Limb Robot Arm System Design and Kinematic Analysis", El-Cezeri Journal of Science and Engineering, 2020, 7 (3): 1320-1331.

[8]. İnternet: https://www.ahmetakgul.com.tr/index.php/uzmanliklar/gerontoloji-yaslanmabilimi/1168- yaslilarda-egzersiz-rehabilitasyon-nasil-yapilmalidir. Erişim Tarihi: 02.01.2021.

[9]. Florini, J. R., Ewton, D. Z. Magri, K. A. "Hormones, growth factors, and myogenic differentiation", Annual Review of Physiology, 1991, 53: 201-216.

[10]. İnternet: https://www.cankayaortopedi.com/hastalar-i\%C3\%A7in/ya\%C5\%9F1\%C4\%B1hastalarda-kal\%C3\%A7a-k\%C4\%B1r\%C4\%B1klar\%C4\%B1. Erişim Tarihi: 02.01.2021.

[11]. Anglin, C., Wyss, U. "Arm motion and load analysis of sit-to-stand, stand-to-sit, cane walking and lifting", Clinical Biomechanics, 2000, 15 (6): 441-448.

[12]. Mustafaoğlu R., "Yaşıı bireylerde ağrıya yaklaşım”, Yaşlı Bakımında Fiziksel Yaklaşımlar, İstanbul Üniversitesi Açık ve Uzaktan Eğitim Fakültesi.

[13]. Faruqui, S., Jaeblon, T. "Ambulatory assistive devices in orthopedics: uses and modifications", The Journal of the American Academy of Orthopaedic Surgeons, 2010, 18 (1): 41-50.

[14]. Wright, D. L., Kemp, T. L. "The dual-task methodology and assessing the attentional demands of ambulation with walking devices", Phys Ther, 1992, 72 (4): 306-312.

[15]. Kuday, I. "Tasarım sürecinin destekleyici faktör olarak biyomimikri kavramının incelenmesi”, Yüksek Lisans Tezi, Mimar Sinan Güzel Sanatlar Üniversitesi, (2009).

[16]. Benyus, J. M. "Biomimicry: Innovation inspired by natüre", William Morrow and Company, New York, (1997).

[17]. Repperger, D. W., Phillips, C. A., Neidhard-Doll, A., Reynolds, D. B., \& Berlin, J. “Actuator design using biomimicry methods and a pneumatic muscle system", Control Engineering Practice, 2006, 14 (9): 999-1009.

[18]. Ball, P. "Natural strategies for the molecular engineer", Nanotechnology, 2002, 13 (5): R15.

[19]. Vincent, J. F. V. "Stealing ideas from nature, deployable structures", Springer-Verlag Wien, New York, (2001).

[20]. Vincent, J. F. V., Bogatyreva, O. A., Bogatyrev, N. R., Bowyer, A., Pahl, A. K. "Biomimetics: its practice and theory", J. R. Soc. Interface, 2006, 3 (9): 471-482.

[21]. Tavsan F., Sonmez E., "Biomimicry in furniture design", 7th World Conference on Educational Sciences, (WCES-2015), Athens, Greece, (2015).

[22]. Top, N., Akboğa, K., Başak, H., Şahin, İ. "Design of a low-volume waiting unit for airports using biomimetic approaches", Gazi University Journal of Science Part A: Engineering and Innovation, 2018, 5 (4): 191-202.

[23]. Bar-Cohen, Y. "Biomimetics: using nature to inspire human innovation", Bioinspiration \& Biomimetics, 2006, 1 (1), P1.

[24]. Genç, M. "Doğa, sanat ve biyomimetik bilim", Sanatta Yeterlik Eseri Çalışması Raporu, Hacettepe Üniversitesi Güzel Sanatlar Enstitüsü, (2013).

[25]. Yıldız, H. "Endüstri ürünleri tasarımı kapsamında biyomimetik tasarımın yeri ve metodolojisi”, Doktora Tezi, İstanbul Teknik Üniversitesi Fen Bilimleri Enstitüsü, (2012).

[26]. Hong, W., Jianfeng, X., Xiangmei, F. "A kind of underwater camera Biomimetic Fish", China Patent, No: CN203996849U, (2014). 
[27]. Jacobsen, S. C., Olivier, M. X., Maclean, B. J. "Method of Sizing Actuators for a Biomimetic Mechanical Joint", United States Patent, No: US20110213599A1, (2009).

[28]. Loeb, G. E., Johansson, R. "Biomimetic tactile sensor", United States Patent, No: US7658119B2, (2007).

[29]. İnternet: https://asknature.org/strategy/rolling-into-a-ball-for-protection/. Erişim Tarihi: 15.12.2020.

[30]. Karabetça, A. R. "Nature inspired architectural designs: using biomimicry as a design strategy". International Conference on New Trends in Architecture and Interior Design, 143151, (2015).

[31]. Benyus J.M. "Biomimicry: Innovation inspired by nature”. Harper Perennial, (2002).

[32]. İnternet: https://biomimicry.net/the-buzz/resources/biomimicry-designlens/. Erişim Tarihi: 02.01.2021.

[33]. Wilson, J. R., Corlett, N. "Evaluation of human work", CRC press, (2005).

[34]. Ulijoszek, S. J., Mascie-Taylar, C. G. N. "Antropometry", The Individual and The Population, Cambridge University Pres Great, Britain, (1994).

[35]. Rodriguez-Añez, C. R. "Anthropometry and it application in ergonomics", Brazilian Journal of Kinanthropometry and Human Performance, 2001, 3 (1): 102-108.

[36]. Helvacılar, E. Eldem, C. "İnsan faktörleri mühendisliği bakış açısı ile askeri mesaj işletim sistemleri", Gazi Journal of Engineering Sciences, 2017, 3 (3): 41-46.

[37]. Vink, P., Koningsveld, E. A. P., Molenbroek, J. F. "Positive outcomes of participatory ergonomics interms of greater comfortand higher productivity", Applied Ergonomics, 2006, 37 (4): 537-546.

[38]. Zhang, B., Álvarez-Casado, E., Sandoval, S. G. T., Mondelo, P. "Using ergonomic digital human modeling in evaluation of workplace design and prevention of occupational hazards onboard fishing vessel" Departament d'Organització d'Empreses - Ponències/Comunicacions de congressos, (2010).

[39]. Keleş, A. E., Keleş, M. K. "İņ̧aat Sektöründe Kullanımı Artan Bilgisayar Yazılımları ve Bilgi Teknolojilerinin İrdelenmesi”, El-Cezeri Journal of Science and Engineering, 2018, 5 (2): 610-617.

[40]. Caputo, F., Greco, A., Fera, M., \& Macchiaroli, R. "Digital twins to enhance the integration of ergonomics in the workplace design”, International Journal of Industrial Ergonomics, 2019, 71: 20-31.

[41]. Takala, E. P., Pehkonen, I., Forsman, M., Hansson, G. Å., Mathiassen, S. E., Neumann, W. P., Sjøgaard, G., Veiersted, K. B., Westgaard, R. H., Winkel, J. "Systematic evaluation of observational methods assessing biomechanical exposures at work", Scand J Work Environ Health, 2010, 36 (1): 3-24.

[42]. Top, N. "Operasyonel ofis mobilyası tasarımının rula yöntemi ile ergonomik analizi ve yeniden tasarımı", Gazi Mühendislik Bilimleri Dergisi, 2019, 5 (3): 290-299.

[43]. Dockrell, S., O’Grady, E., Bennett, K., Mullarkey, C., Mc Connell, R., Ruddy, R., Twomey, S., Flannery, C. "An investigation of the reliability of rapid upper limb assessment (RULA) as a method of assessment of children's computing posture", Applied Ergonomics, 2012, 43 (3): 632-636.

[44]. Eldem, C., Top., N. \& Şahin, H. "Dijital insan modelleri kullanarak otomobil sürücüsü duruş pozisyonlarının ergonomik değerlendirilmesi üzerine bir çalışma", Gazi Mühendislik Bilimleri Dergisi, 2019, 5 (1): 22-31.

[45]. Vaclav, S., Peterka, J., Pokorny, P. "Objective method for assembly", In Annals of DAAAM for 2007 \& Proceedings., Viedeň, (2007).

[46]. Qutubuddin, S. M., Hebbal, S. S., Kumar, A. C. S. "Ergonomic risk assessment using postural analysis tools in a bus body building unit", Industrial Engineering Letters, 2013, 3 (8): 10-20. 